\title{
PELATIHAN PEMANFAATAN MULTIMEDIA BAGI GENERASI MUDA GEREJA DI KELURAHAN MATANI 1 KOTA TOMOHON
}

\author{
Arje Cerullo Djamen ${ }^{1}$ ) Wensi Ronald Lesli Paat ${ }^{2}$ ) \\ Fakultas Teknik, Universitas Negeri Manado 1),2) \\ email : arjedjamen@unima.ac.id 1), \\ wensipaat@unima.ac.id 2)
}

\begin{abstract}
Globalisasi telah memicu kecenderungan terjadinya pergeseran atau perubahan diberbagai bidang. Era globalisasi identik dengan perkembangan teknologi informasi disegala bidang, mulai lingkungan sosial, ekonomi, teknologi, politik,pendidikan sampai pada bidang kerohanian. Metode yang digunakan adalah dengan presentasi, tanya jawab, demonstrasi, pemberian tugas dan studi kasus. Target pelaksanan Pelatihan ini yaitu: (1). Pemanfaatan multimedia dalam kegiatan pelayanan yang berkualitas. (2). Dapat meningkatkan kemampuan sumber daya manusia dari generasi muda dalam memanfaatan multimedia. (3).Pemaanfaatan multimedia dalam kegiatan pelayanan membuat kegiatan pelayanan lebih aktif dan menarik. (4). Pemanfaatn multimedia lebih terarah kearah yang lebih positif. Luaran dari kegiatan ini adalah (1) Meningkatkan kemampuan para generasi muda dalam memanfaatkan multimedia dengan baik dalam proses kegiatan pelayanan. (2) Meningkatkan kualitas pelayanan yang ada di gereja, dengan memanfaatkan multimedia dalam pelayanan. . Prosedur pelaksanaan kegiatan ini dibagi menjadi 4 tahapan yaitu yang digunakan adalah perencanaan, pelaksanaan/tindakan, evaluasi dan refleksi hasil kegiatan, dan yang terakhir pelaporan hasil kegiatan. . Sasaran kegiatan ini adalah para g enerasi muda yang ada di Kelurahan Matani 1 Kota Tomohon. Pelaksanaan kegiatan PPM di Kelurahan Matani 1 dirasakan oleh pelaksana maupun peserta sangat memuaskan. Dengan indikator kehadiran peserta dan antusias peserta pelatihan cukup baik. Hasil dari pela tihan sudah cukup baik. Suasana belajar dan tutorial cukup bagus. Hampir semua peserta mengikuti dari awal sampai akhir. Para pejabat terkait sangat mendukung pelaksanaan pengabdian masyarakat yang dilaksanakan oleh pelaksana.
\end{abstract}

Keywords: Multimedia, teknologi informasi dan komunikasi 


\section{PENDAHULUAN}

\section{A. Analisis Situasi}

Globalisasi telah memicu kecenderungan terjadinya pergeseran atau perubahan diberbagai bidang. Era globalisasi identik dengan perkembangan teknologi informasi disegala bidang, mulai lingkungan sosial, ekonomi, teknologi, politik,pendidikan sampai pada bidang kerohanian. Teknologi informasi adalah suatu teknologi yang digunakan untuk mengolah data, termasuk memproses, mendapatkan, menyusun, menyimpan, memanipulasi data dalam berbagai cara untuk menghasilkan informasi yang berkualitas, yaitu informasi yang relevan, akurat dan tepat waktu, yang digunakan untuk keperluan pribadi, bisnis, dan pemerintahan dan merupakan informasi yang strategis untuk pengambilan keputusan. Peran yang dapat diberikan oleh aplikasi teknologi informasi ini adalah mendapatkan informasi untuk kehidupan pribadi seperti informasi tentang kesehatan, hobi, rekreasi, dan rohani. Teknologi informasi adalah media atau alat yang diciptakan oleh manusia, dan manusia memerlukan teknologi informasi untuk melakukan pekerjaannya. Multimedia merupakan salah satu bagian dari teknologi informasi. Multimedia adalah media atau alat yang dapat menciptakan presentasi yang dinamis dan interaktif yang mengkombinasikan teks, grafik, animasi, video dan gambar video. Pengembangan teknologi perlu didukung dengan Sumber Daya Manusia (SDM) yang berkualitas. Bagaimanapun juga SDM dan teknologi informasi merupakan dua komponen yang tidak bisa dipisahkan. Keduanya memiliki hubungan timbal balik. Secanggih apapun media yang tersedia tidak akan dapat dimanfaatkan secara maksimal apabila tidak didukung oleh pengguna atau user yang berkualitas. Sebagian besar pengguna adalah yang tergolong orang yang masih berusia muda. Hal ini disebabkan karena usia muda lebih cenderung aktif, mobile, dan selalu mengikuti perkembangan zaman.

Perkembangan multimedia bukan hanya dikalangan perkotaan besar tapi juga merambah ke daerah-daerah. Kota Tomohon, merupakan salah satu kota yang perkembangan multimedianya cukup pesat. Meskipun demikian masih banyak masyarakat dalam hal ini yang berusia muda yang belum mengetahui secara jelas tentang pemanfaatan multimedia.
Banyak yang memanfaatkan multimedia itu sendiri hanya sebagai media untuk mendengarkan musik, menonton video dan film, mengedit dan melihat gambar. Dilain pihak, multimedia merupakan media yang memiliki banyak manfaat karena dapat diimplementasikan diberbagai bidang. Tidak bisa dipungkiri, banyak anak muda menyalahgunakan penggunaan multimedia. Multimedia sering juga digunakan untuk hal-hal negatif yang dapat memberikan dampak buruk. Minimnya pengetahuan tentang pemanfaatan multimedia membuat multimedia itu sendiri tidak dimanfaatkan secara maksimal.

Perkembangan teknologi dalam hal ini pemanfaantan multimedia tidak hanya untuk kalangan umum saja, tetapi sudah masuk dalam lingkungan gereja dalam hal ini untuk kegiatan pelayanan kerohanian untuk itu perlu adanya pelatihan bagi anak-anak muda khususnya bagi pemuda gereja, agar pemanfaatan multimedia dalam kegiatan pelayanaan kerohanian dapat dimaksimalkan dengan baik.

\section{B. Permasalahan Mitra}

Sebagai mitra dalam pelaksanaan kegiatan pengabdian masyarakat ini adalah Pemuda Gereja di Kelurahan Matani 1 Tomohon. Berdasarkan analisis situasi dapat teridentifikasi beberapa permasalahan yang dihadapai oleh mitra, yaitu

1. Pemanfaatan Teknologi Multimedia yang belum optimal

2. Kurangnya pengetahuan bagi pemuda gereja untuk memanfaatkan multimedia dengan baik

3. Peningkatan kualitas pelayanan di gereja

Dalam identifikasi permasalahan yang ada, maka yang menjadi prioritas dalam hal ini adalah para pemuda gereja, dimana para pemuda ini merupakan penopang utama dalam kegiatan pelayanan terutama dalam hal penggunaan dan pemanfaatan teknologi multimedia. Dengan adanya pengetahuan yang dimiliki serta skil dalam pemanfaatan penggunaan teknologi multimedia, maka akan mendorong kualitas dalam kegiatan pelayanan gereja.

Dengan kemampuan penggunaan dan pemanfaatan teknologi multimedia ini, diharapkan akan memberi dampak positif bagi para pimpinan gereja serta para jemaat bahwa dengan penggunaan teknologi multimedia ini 
akan lebih memotivasi para pimpinan gereja serta jemaat dalam hal menumbuhkembangkan kualitas dalam kegiatan pelayanan. Peran serta pihak pemerintah dan pimpinan organisasi gereja yang ada akan sangat penting bagi pelayanan organisasi gereja tersebut dalam hal pengadaan fasilitas penunjang dalam proses pelayanan di gereja.

\section{TARGET DAN LUARAN}

\section{A. Target}

Target pelaksanan Pelatihan Pemanfaatan Multimedia Bagi Pemuda Gereja di Kelurahan Matani 1 Kota Tomohon, yaitu:

1. Pemanfaatan multimedia dalam kegiatan pelayanan yang berkualitas.

2. Dapat meningkatkan kemampuan sumber daya manusia dari pemuda gereja dalam memanfaatan multimedia

3. Pemaanfaatan multimedia dalam kegiatan pelayanan membuat kegiatan pelayanan lebih aktif dan menarik

4. Pemanfaatn multimedia lebih terarah kearah yang lebih positif.

\section{B. Luaran}

Untuk mengatasi permasalahan yang dihadapi dengan sasaran para Pemuda Gereja di Kelurahan Matani 1 Kota Tomohon diperoleh berbagai bentuk luaran, yaitu:

1. Meningkatkan kemampuan para pemuda gereja dalam memanfaatkan multimedia dengan baik dalam proses kegiatan pelayanan.

2. Meningkatkan kualitas pelayanan yang ada di gereja, dengan memanfaatkan multime dia dalam pelayanan.

\section{METODE}

\section{A. Metode Kegiatan}

Inti pelaksanaan program ini adalah mengadakan pelatihan atau workshop tentang pemanfaatan multimedia di Kelurahan Matani 1 Kota Tomohon. Kegiatan ini bertujuan untuk mendorong dan memotivasi para pemuda gereja agar lebih . aktif, kreatif dan inovatif dalamn memanfaatkan multimedia dengan baik.. dengan perkembangan multimedia ini, diharapkan dapat menjembatani para pemuda gereja untuk memiliki ketertarikan dalam belajar bagaimana memanfaatkan multimedia itu dengan baik, dan bisa membawa manfaat bagi mereka dalam hal pengembangan diri.

Untuk melaksanakan kegiatan ini, maka dilaksanakan secara bermitra antara tim pelaksana yaitu dari dosen Program Studi Pendidikan Teknologi Informasi dan Komunikasi (PTIK) Fakultas Teknik Universitas Negeri Manado dengan Pimpinan Gereja yang ada di Kelurahan Matani 1

\section{B. Prose dure Pelaksanaan Kegiatan}

Agar pelaksanaan ipteks Kegiatan ini lebih terarah, maka prosedur pelaksanaan kegiatan ini dibagi menjadi 4 tahapan yaitu yang digunakan adalah perencanaan, pelaksanaan/tindakan, evaluasi dan refleksi hasil kegiatan, dan yang terakhir pelaporan hasil kegiatan. Adapun uraian dari setiap tahapan kegiatan adalah sebagai berikut :

1. Tahap Perencanaan

Tahapan ini dilakukan setelah dilaksanakan survey dan analisa situasi terhadap lokasi kegiatan. Kegiatan yang dilakukan pada tahapan ini adalah tim pelaksana berkomunikasi dengan kepala Pimpinan Gereja yang akan menjadi mitra untuk membicarakan maksud dan tujuan, serta mekanisme pelaksanaan kegiatan ini. Selain itu juga membicarakan hal-hal teknis yang mengenai pelaksanaan kegiatan. Setelah mengkoordinasikan pelaksanaan kegiatan maka tim pelaksana menyusun program pelatihan atau workshop. Selain itu juga pada tahapan ini dilakukan pengumpulan alat dan bahan yang akan digunakan.

\section{Pelaksanaan Pelatihan}

Sebelum pelaksanaan kegiatan inti dilakukan, maka dilakukan persiapan terlebih dahulu yaitu pengecekan kembali seluruh peralatan yang akan digunakan, membagi peserta menjadi beberapa kelompok sesuai dengan bidang ilmu yang diajarkan di sekolah masing-masing.

Tahpan ini merupakan tahapan pelaksanaan pelatihan atau workshop pelaksanaannya dikerjakan sesuai dengan program yang telah dibuat. Pelatihan atau workshop yang dimaksudkan direncanakan akan diadakan dalam 3 bagian, yaitu (1) Pengenalan dari beberpa media yang akan digunakan ; (2) Pengenalan aplikasi yang di gunakan dalam kegiatan pelayanan; (3) Presentasi aplikasi multimedia yang digunakan dalam kegiatan pelayanan 
Untuk melaksanakan kegiatan tersebut digunakan beberapa metode pelatihan. Adapun metode yang digunakan, yaitu :

a. Metode Ceramah

Metode ceramah dipilih untuk memberikan penjelasan pemanfaatan multimedia dalam kegiatan pelayanan

b. Metode Tanya Jawab

Metode tanya jawab sangat penting bagi para peserta pelatihan, baik di saat menerima penjelasan tentang serta saat mempraktekkannya, metode ini memungkinkan peserta menggali pengetahuan sebanyak-banyaknya tentang materi yang diberikan dan juga pengalaman setelah praktek.

c. Metode Simulasi

Metode simulasi ini sangat penting diberikan kepada para peserta pelatihan untuk memberikan kesempatan mempraktekan materi pelatihan yang diperoleh. Harapannya, peserta pelatihan akan benarbenar menguasai materi pelatihan yang diterima, mengetahui tingkat kemampuannya menerapkan secara teknis dan kemudian mengidentifikasi kesulitankesulitan (jika masih ada) untuk kemudian dipecahkan.

3. Evaluasi dan Refleksi

Pelaksanaan evaluasi terhadap peserta, sehingga dapat diketahui sejauh mana pemahaman peserta terhadap apa yang diberikan. Evaluasi juga dilakukan terhadap tingkat pemahaman peserta secara teori dan praktek. Refleksi dilakukan terhadap sejauhmana tingkat keberhasilan kegiatan yang telah dilaksanakan. Selain itu juga bertujuan untuk mengetahui kekurangan dan kelebihan dari kegiatan-kegiatan yang telah dilaksanakan dalam rangka untuk menetapkan rekomendasi terhadap keberlangsungan atau pengembangan kegiatan-kegiatan berikutnya. Dengan kata lain ada tindak lanjut program yang sama.

4. Pelaporan Hasil Kegiatan

Setelah pelaksanaan kegiatan selesai, maka dibuat pelaporan dari hasil kegiatan yang telah dilaksanakan sebagai bukti pertanggungjawaban terhadap instansi yang menugaskan, bahwa kegiatan telah dilaksanakan.

\section{Khalayak Sasaran}

Sasaran kegiatan ini adalah para Pemuda gereja di Kelurahan Matani 1 Kota Tomohon. Pemilihan dan penetapan sasaran pelatihan ini mempunyai pelaksanaan pengembangan rasional-strategis dalam kaitannya dengan upaya peningkatan kualitas para pemuda gereja. Kegiatan pelatihan ini merupakan bentuk pembinaan kemampuan pemuda gereja dalam memanfaatkan multimedia itu dengan baik.

\section{Kelayakan Perguruan Tinggi}

Kegiatan Pengabdian pada Masyarakat merupakan salah satu bentuk perwujudan dari Tri Dharma Perguruan Tinggi yaitu melaksanakan pengabdian kepada masyarakat. Pelaksanaan pengabdian pada masyarakat untuk Unima berada di bawah tugas dan kewenangan dari Lembaga Pengabdian Kepada Masyarakat (LPM) Unima. Dalam beberapa tahun terakhir LPM Unima selalu aktif dalam memberikan informasi kepada semua dosen yang ada di lingkungan Unima mengenai adanya usulan kegiatan pengabdian pada masyarakat bagi pendanaan yang bersumber BOPTN atau DIPA Unima maupun yang dibiayai oleh Dikti. Usulan kegiatan pengabdian yang dibiayai oleh Unima direview oleh reviewer internal yang berkompeten dan profesional dalam melaksanakan kegiatan pengabdian pada masyarakat.

Berdasarkan alasan tersebut, maka pelaksana program pengabdian kepada masyarakat Unima dari Prodi PTIK Fakultas Teknik UNIMA merasa layak serta memiliki kemampuan yang memadai dalam melaksanakan pengabdian melalui pelatihan pengembangan media pembelajaran berbasis multimedia :

1. Pelaksana terdiri dari disiplin ilmu dibidang teknologi informasi dan komukasi.

2. Bidang keahlian pelaksana pelaksana sangat relevan dengan jenis kegiatan yang akan dilakukan dalam upaya pemberdayaan pada Pemuda gereja, karena bentuk pemberdayaan yang akan dilakukan kepada masyarakat lebih mengarah pada pembentukan kemandirian melalui pendidikan.

3. Ketua pelaksana memiliki keahlian dalam bidang pendidikan teknologi informasi dan komunikasi, secara umum sebagai memiliki keahlian dibidang pendidikan yang sesuai dengan jurusan yang menjadi tempat 
pelaksanaan pekerjaan. Dengan demikian keahlian tersebut, sebagai ketua merasa mampu dan yakin dapat memberikan pelatihan pada Pemuda gereja di Kelurhan Matani.

\section{HASIL DAN PEMBAHASAN}

Dalam pelaksanaan kegiatan ini, dosen dibantu oleh pegawai administrasi dan dibantu juga oleh 2 orang mahasiswa Fakultas Teknik Program Studi PTIK UNIMA.

Metode yang digunakan adalah dengan presentasi, tanya jawab, demonstrasi, pemberian tugas, dan studi kasus. Pada akhir pelaksanaan pelatihan, diberikan kesempatan kepada setiap peserta untuk memberikan tanggapan terhadap pelaksanaan pelatihan ini serta memberikan pemahaman tentang bahan pelatihan yang sudah diikuti sehingga lewat tanggapan-tanggapan tersebut dapat dijadikan bahan penilaian untuk melihat tingkat keberhasilan dari pelatihan yang sudah diberikan.

Untuk menilai menilai sejauh mana keberhasilan pelaksanaan kegiatan program penerapan IPTEKS ini, telah dilakukan evaluasi terhadap peserta. Evaluasi dilakukan selama kegiatan dengan memberikan beberapa tugas yang harus dikerjakan oleh semua peserta dan melakukan tanya jawab. Semua hasil tugas dan hasil tanya jawab dijadikan sebagai bahan penilaian keberhasilan pelatihan yang telah dilaksanakan. Seluruh hasilnya dirangkum sebagai berikut :

1. Adanya respon positif dari pimpinan gereja dan anggota jemaat

2. Semua peserta telah menunjukkan kesungguhan dalam mengikuti pelatihan ini mulai dari awal kegiatan sampai pada akhir kegiatan.

3. Semua peserta sangat antusias, hal tersebut nampak jelas ketika peserta harus mempraktekan langsung, baik secara individu maupun kelompok

4. Peserta menjadi lebih kreatif dan inovatif

5. Para peserta mengakui bahwa pelatihan ini sangat perlu karena selama ini pengetahuan yang mereka miliki tentang multimedia masih minim

6. Para peserta berhasil mengerjakan latihanlatihan yang diberikan

7. Para peserta pada umumnya menyatakan bahwa mereka merasa beruntung memperoleh kesempatan mengikuti pelatihan ini, dan mereka mengharapkan Unima untuk melaksanakan kegiatan lanjutan

8. Para peserta menyatakan terima kasih kepada pelaksana.

Dari penjelasan diatas, maka dapat dikemukakan beberapa hal sebagai berikut :

1. Pelatihan multimedia bagi pemuda gereja yang walaupun singkat pelaksanaannya merupakan salah satu bentuk kegiatan yang efektif dalam mendorong tumbuhnya keterampilan, motivasi, kreativitas, serta inovatif

2. Teknologi informasi sangat penting dalam menunjang berbagai bidang kehidupan

3. Program Studi PTIK Fakultas Teknik UNIMA sangat dibutuhkan diberbagai bidang guna meningkatkan kualitas berbagai bidang di Sulawesi Utara.

\section{KESIMPULAN DAN SARAN}

A. Kesimpulan

1) Kegiatan pengabdian masyarakat ini berbentuk pelatihan singkat kepada para pemuda gereja telah berhasil dilaksanakan dengan baik dan mencapai tujuan yang diharapkan

2) Kegiatan ini dapat membantu perluasan pengetahuan, keterampilan, motivasi, kreativitas serta inovatif dalam menggunakan dan memanfaatkan multimedia secara maksimal, tepat dan benar.

3) Kegiatan ini sebagai uasaha pemerataan IPTEKS di daerah Sulawasi Utara, dimana teknologi bukan hanya diperutukan oleh masyarakat kota besar

4) Kegiatan ini merupakan bagian dari upaya peningkatan kualitas pemuda gereja

5) Kegiatan ini telah memberikan kontribusi bagi LPM UNIMA untuk mempertimbangkan dalam menetapkan program-programnya diwaktu yang akan datang.

B. Saran

1) Kegiatan pengabdian kepada masyarakat seperti ini perlu dilajutkan dengan materi dan kegiatan yang sama tapi dapat dilaksanakan ditempat yang berbeda, ataupun materi yang berbeda ditempat yang sama. 
2) Hubungan kerja sama antara UNIMA dengan pemerintah mulai dari pemerintah provinsi sampai pemerintah desa/kelurahan melalui Lembaga Pengabdian Masyarakat yang selama ini telah terjalin perlu ditingkatkan dan diperluas dalam menangani permasalahan yang berhubungan dengan teknologi informasi.

3) Setiap tenaga akademik di Perguruan Tinggi (Dosen) khusunya UNIMA hendaknya peka terhadap kondisi masyarakat serta peroalan yang ada didalamnya, dengan cara memberikan solusi-solusi yang bermanfaat dan berdampak positif.

\section{REFERENSI}

Abdul Kadir dkk. (2003). Pengenalan Teknologi Informasi, Yogyakarta : ANDI Yogyakarta.

Burch, Johm, G. Dkk. (1989). Information System Theory and Practice. Edition : John Wiley \& Sins, Inc.

Lucas Henry J. (2000). Information Technology for Management. Irwin/MacGraw Hill.

Suyanto, M. (2003). Multimedia (alat untuk meningkatkan keunggulan bersaing). Yogyakarta : Penerbit Andi. 